\title{
Politeness Strategies in Making Requests in Jordanian Call-Centre Interactions
}

\author{
Faten Amer (Corresponding Author) \\ Centre for International Languages (CIL), Universiti Malaysia Perlis, Malaysia \\ E-mail: fatenamer@gmail.com \\ Dipima Buragohain \\ Centre for International Languages (CIL), Universiti Malaysia Perlis, Malaysia \\ E-mail:dipima@unimap.edu.my \\ Ina Suryani \\ Centre for International Languages (CIL), Universiti Malaysia Perlis, Malaysia \\ E-mail: inasuryani@unimap.edu.my
}

Received: January 20, 2020 Accepted: February 6, 2020 Published: February 8, 2020

doi:10.5296/elr.v6i1.16283

URL: https://doi.org/10.5296/elr.v6i1.16283

This article is extracted from a PhD thesis written by the first author and supervised by the co-authors.

\begin{abstract}
The aim of this study is to examine politeness strategies employed in the interactions between Jordanians and the employees of the call-centre-customer service (CCCS) of a major telecommunications company in Jordan. It focuses on their linguistic behaviours upon requesting taking into account the variables of gender, and reasons for calling that may affect the choice of selecting an appropriate strategy. The data were collected from 20 participants through recording of naturally-occurring interactions. The theoretical framework of this study is based on Brown and Levinson's (1987) model of politeness. The results of the study have shown that negative-politeness strategies dominate the scene in making requests as they were the most frequent ones which may indicate the preference of Jordanians for these strategies to
\end{abstract}


other strategies. Furthermore, the results have shown that in certain cases gender variation had an impact on the choice of particular strategies.

Keywords: Requests, Politeness strategies, Jordanian Arabic, Gender, Context, Indirectness

\section{Introduction}

In politeness research, the speech act of requests is a central issue as it is a frequent act in everyday communication (Uso-Juan, 2010). Requests are called pre-event acts for the fact that they result in an action in the event (Blum-Kulka \& Olshtain, 1984; Uso-Juan, 2010). They are classified as face-threatening acts (FTAs) since they entail a threat to the speaker's as well as the hearer's face wants (Yule, 1996). In performing requests, the speaker (known as the requester) performs a request to get some actions done for him or her by the hearer (known as the requestee).

Requests, as speech acts, are categorised into direct and indirect requests (Searle,1979). The direct requests refer to those acts which can be understood clearly by the addressee without the need for any inference, so they are 'locutionary acts' in Austin's (1962, p. 99) terms, whereas the indirect requests are "illocutionary acts" requiring the hearer's own inference as the meaning is not directly shown by the words contained in the sentence. When interlocutors do not share cultural or social backgrounds, these illocutionary acts will be somehow difficult to interpret and may result in misunderstanding between the two interlocutors (Eslami \& McLoed, 2010).

When a request is direct, the hearer has no difficulties in evaluating the request so he or she has either to comply with the request or not. As for the indirect request, there will at least two meanings (Searle, 1975): the literal meaning which is interpreted through the meaning of the individual words that constitute the sentence and the grammatical form of that sentence. For example, the sentence 'Could you lend me your car, please?' can be responded to by the hearer in two ways: (1) using the literal meaning of the sentence eliciting responses as 'Yes, I can' or 'No, I cannot', and (2) using the pragmatic meaning, the intended meaning of the speaker eliciting responses like 'Sure, here are the keys' or 'I am sorry, I have to go somewhere in a moment'. For hearers deciding successfully upon intended meaning of an indirect request to comply with, i.e. the pragmatic meaning, a number of variables they consider including their relationship with the speaker, time, place and other social and cultural variables.

\section{Literature Review}

Speech acts, a central concept in pragmatics, were first introduced by Austin (1962) through his famous lectures How to Do Things with Words. Austin (1962) was the first to coin the concept of speech act as he stated that performatives are utterances which not only convey a proposition but also perform an action, i.e. words are actions in themselves because they are uttered either to do something or to get something done by others. According to Austin's theory, when we speak; we at the same time perform three acts:

Locutionary act: Articulate an utterance which has sense and reference such as 'Could you 
tell me what happened?'. In other words, it is the ostensible meaning.

Illocutionary act: Through the utterance we can make a request, for example. The utterance carries a communicative value that can be understood by the hearer, the intended meaning.

Perlocutionary act: The effect which the utterance brought to the hearer, for example, to do the speaker's request or getting them realise something whether intended or not.

The above classification can be summarised as: what a speaker says, what he/she intends to achieve by saying this utterance (the force behind it) and the effect of the given utterance on the addressee.

Searle (1969) developed Austin's speech acts hypothesising that four types of acts are performed in speaking: a) utterance acts; b) propositional acts; c) illocutionary acts; and d) perlocutionary acts. He improved Austin's illocutionary acts forces suggesting four underlying conditions associated with speech acts. Searle (1969, pp. 62-63) called these conditions "felicity conditions" which include: rule of propositional content, preparatory conditions, sincerity conditions and essential rule.

According to preparatory conditions and essential rule, in orders and commands, the speaker must be in authority over the hearer and the utterance should count as an attempt to get the hearer do the act because of the speaker's authority over him. Requests are different from orders because the requester has no authority over the requestee. In addition, the requester is not insistent and would not be angry if his request is met with refusal (Green, 1996).

Later, Searle (1976, pp. 10-15) proposed a much widely accepted idea suggesting five types of utterances, which include both speaker and hearer (representatives, directives, commissives, expressives and declarations). Whatever the type of the speech act is, it should be clear enough to communicate the meaning the speaker tends to convey. For this reason, there should be a kind of cooperation between the speaker and the hearer although the speaker's cooperation is more important than that of the hearer because the speaker is required to be clear, relevant, etc. to allow the hearer to understand the act, a framework suggested by Grice (1975).

Grice's (1975) cooperative principle (CP, henceforth) aims to describe the ordinary linguistic behaviour of people in conversation, i.e. the way they interact with one another in order to offer a framework for language use. Conforming to $\mathrm{CP}$, participants in a conversation attempt to make certain that what they say achieves the goal of their conversation. According to $\mathrm{CP}$, for interlocutors to produce appropriate conversational behaviour, they have to keep in mind four maxims: maxim of relation, maxim of quality, maxim of quantity and maxim of manner (Grice, 1975, pp. 45-47). Once these maxims are followed by the interlocutors of a conversation, there will be what Grice (1989, p. 28) called "the effective exchange of information".

\subsection{Politeness Theories}

One of the most important issues in politeness is 'face'. According to Eshreteh (2014), every individual has to think twice before uttering a word and many times before performing an 
action to avoid losing face or creating a clash between one's face wants and others' which will be difficult to resolve and restart again.

Goffman defines face as "the positive social value a person effectively claims for himself by the line others assume he has taken during a particular contact" (1967, p. 5). In addition, it is "an image of self delineated in terms of approved social attributes ..." (ibid). Goffman (1967, pp. 15-20) argues that there are two main processes involved in face-work: "the avoidance process" and "the corrective process".

Brown and Levinson are regarded as the most popular scholars in developing the research in speech acts and politeness phenomena within human communication (Ji, 2000). Brown and Levinson (1978) put forward the most influential model of politeness. Their point of departure was the ideas of face proposed by Goffman (1967). Relying on their observations of similarities in the linguistics strategies used by different speakers of different languages, Brown and Levinson (1978) establish that politeness is a universal phenomenon. Their model is founded on the construction of a fluent speaker of a natural language known as a Model Person (MP) who is characterised by two main features: "rationality" and "face" (Brown \& Levinson, 1987, p. 58). They define rationality as the MP's ability to be engaged in means-ends analysis. By reasoning from ends to the means the MP fulfils his/her ends. They define 'face' as the public self-image that the MP desires to have. Brown and Levinson (1987) claim that there are two aspects of face:

Positive face refers to the interactant's positive self-image. It is their wish to be approved in certain respects by others. In other words, it is their wish to be desirable to others and that the self-image be appreciated, 'the wants of approval' (Kasper, 1998).

Negative face refers to the interactant's want to be unimpeded by others. It is their 'basic claim to territorial personal preserves and rights to non-distraction'. In other words, it is their wish to be free from imposition by others, 'the wants of self-determination' (Kasper, 1998).

According to Brown and Levinson (1987, p. 69), there are five possible choices to reduce the degree of the face-threatening acts (FTAs). The speaker uses the first strategy "without redressive action" in the situation he expects no face loss from or on the hearer, that means the act will cause no face loss for either of them. Strategies 2 and 3 include redressive action in which the speaker attempts to reduce the expected FTA and at the same time tries to save his face. They use "conventionalised indirectness", in Brown and Levinson's (1987, p. 70) terminology, to do negative politeness as indirect requests are on record such as, 'Can you pass the salt?'. Speakers employ an "off record", the fourth strategy, when they expect that the speech act will cause them great face loss. In this strategy, they leave the intended or implied meaning to be interpreted by the hearer, somehow similar to Grice's flouting the maxim. The fifth strategy "Don't do the FTA" is similar to the fourth strategy in that speakers feel that their request will cause them great face loss, but different in that they feel that no linguistic strategy is enough to manage the face threat and as a result they take the decision not to do the act. 


\subsection{The Previous Studies}

Studies on linguistic politeness are countless in number. The literature on this phenomenon is very rich. In Jordanian Arabic (henceforth, JA) many studies have been conducted in terms of speech acts aiming at establishing a kind of relation between them and some selected social variables (e.g., Al-Qudah, 2017; Abushihab, 2015; Bani Mofarrej \& Al-Abed Al-Haq, 2015; Al-Harahsheh, 2014a; Almutlaq \& Jarrah, 2013; Al-Khawaldeh \& Zegarac, 2013; Al-Sobh, 2013; Rababa'h \& Malkawi, 2012; Al-Momani, 2009, among others). As for the present study, it focuses on the differences in the expressions of requesting acts by Jordanian males and females found in their naturally-occurring interactions with the call-centre-customer service of a leading telecommunications company in Jordan.

Cultural differences are also reflected by differences in gender practices which may also differ from one group to another. Eckert (1998) and Holmes (2008) state that because women are more status-conscious or polite and men are tough, their language is more conservative than that of men. Women in Jordan have been sometimes considered violating the social norms of Jordanian society because they use unusual pronunciation for which they are criticised (Al-Harahsheh, 2014b).

Investigating the gender differences between women's and men's language in Jordanian Arabic, Al-Harahsheh (2014b) analyses twelve dyadic conversations produced by students of a Jordanian university to find out whether women use more politeness strategies than men. The findings of the study show that there are significant differences between the linguistic styles of women and men in that women have a tendency to maintain social relationship with the other interlocutor and avoid direct disagreement. Furthermore, they try to get the listener engaged in the conversation by using more facilitative strategies. The author concludes women are professional conversationalists and show more cooperation than men do.

Investigating the gender influence on the expressions of gratitude in Jordan, Al-Khawaldeh and Zegarac (2013) interviewed 10 male and 10 female postgraduate Jordanian students from southern and northern tribal rural parts of Jordan as representative of the national culture. The results of the study show that there are some differences between men and women in both types of interactions she used: same-gender and mixed-gender ones. For example, female-participants appear to value expressing gratitude more than male-participants do; women have a tendency to use gratitude to women more than men do to men whereas men show more politeness when addressing women especially in unfamiliar contexts.

Another study that is relevant to the present study was conducted by Migdadi (2003). It is relevant to the present study in that it investigates the relationships between compliments and gender differences (among other variables). Among the findings of the study is that Jordanian Arabic speakers who share same gender and age use compliments when speaking to each other more frequently than people who differ from each other in these categories. As far as gender and age are concerned, female and young people tend to use compliments more than other groups in the following categories: compliments on appearance, explicit compliments and compliment plus explanation. Finally, when performing compliments, Jordanian men use blessings and disagreements whereas women use questions. 
As far as gender in the Jordanian context is concerned, Bani Mofarrej and Al-Abed Al-Haq (2015) study the use of euphemistic death expressions in the Jordanians society. They randomly selected 130 male and female participants in order to investigate the use of these expressions mapping them on gender, age and region as social variables. They conclude that Jordanian Arabic speakers use euphemistic death expressions in order to maintain politeness and sympathy during death occasions saving their own faces and the other people's faces. The results also show that religious values and beliefs influence the use of death expressions. As for the social factors: age, gender and region, they state that they do not have much influence on the use of euphemistic death expressions attributing such a finding to the direct contact between Jordanians of different ages, genders and regions which makes them use similar expressions. Moreover, the absence of differences under these variables was attributed to the topic as being sensitive in which people use almost same expressions in order to show politeness and respect. Finally, the results show that Jordanian people feel free to talk about death directly but are more polite when addressing the people whose relations or friends have recently died.

Similar variables are considered by Al-Harahsheh (2014a) who studies silence as a speech act in 12 casual conversations of 24 Jordanian university students of both genders. He finds that silence has some functions and meanings in the Jordanian society with various interpretations according to context, topic and the relationships between the interlocutors. The results of the study indicate that the majority of the participants consider silence a kind of impolite behaviour. For this reason, the author states that "Silence is not of Jordanian culture nowadays" (p. 20) because Jordanians like to talk when useful rather than to keep silent to strengthen the social ties between them. However, they prefer silence when speaking can result in undesired argument or can hurt other interlocutors' feelings. Al-Harahsheh (2014a) concludes that meaning of silence is ambiguous and can be interpreted in various ways according to the body language of the speaker, the shared background knowledge, the linguistic environment, i.e. the preceding and following utterances and the context of the interaction.

Similar to the above context is a study conducted by Rababa'h and Malkawi (2012) in which they investigate the sociolinguistic politeness of greetings used by Jordanian people in their social interactions focusing on the factors that govern their forms. They collected 100 spontaneous interactions from various rural areas in Irbid (Irbid is a city situated in north of Jordan). The results of the study show that males tend to use more polite terms greeting other males and less polite ones when greeting females. Women themselves use less formal and less polite terms in their use of greetings but they achieve higher degree of intimacy by adding appropriate cultural relational terms of address and low-pitched tone to their greetings. Gender differences also show that certain greetings such as 'good morning' are sex-marked, used mostly by women, whereas cultural greetings such as "gaww illghaanmiin" (May Allah strengthen the noble) are sex and age markers, used mostly by men (Rababa'h \& Malkawi, 2012, p. 26).

The above studies investigated a number of speech acts in the Jordanian context relating them 
to different social variables including age, gender, region, religion, relationships, etc. Although similarities in the findings of these studies exist, their findings differ from one study to another depending on the place where the study was conducted. This variation in the results of the previous research on social variables roles in politeness in the JA context gave rise to this study as it aims to investigate these variables in a context that, to the best knowledge of the researcher, has not been approached in general, the interactions between Jordanian people and government or private organisations, and the context of CCCS of telecommunications companies in particular. Thus, this constitutes a gap in the literature on politeness behaviour in the Jordanian Arabic context. Therefore, this study aims and hopes to enrich the literature on the JA context by bridging the above-mentioned gap.

\section{Methodology}

Data for this study were collected from the interactions of 20 participants; they were randomly chosen from the employees of the CCCS of the telecommunications company and customers using theoretical framework based on Brown and Levinson's (1987) model of politeness. Their ages, genders and social statuses were uncontrollable as the researcher could not do any pre-interaction arrangements with them because interactions were naturally-occurring ones. The participants were divided into two groups: the customers (C) and the call centre's employees (E). The study involved qualitative data collection using recordings of naturally-occurring interactions that took place between the customers and the call centre's employees. Being spoken in Arabic, the data was transcribed and translated into English then grouped into themes according to the politeness strategies used by the participants.

\section{Findings and Discussion}

A request is classified as a speech act in which a person, the speaker, indicates to another person, the hearer, that the speaker wants the hearer to do an act which is for the benefit of the speaker (Trosborg, 1995). It is a face threatening act (FTA) since the speaker, one who makes the request, tries to exercise power over the hearer. In other words, the speaker threatens the hearer's negative face since he does not mean to impede the hearer's freedom of action. The speaker also risks losing face because the hearer may or may not achieve the speaker's desire.

Brown and Levinson (1987, p. 69) proposed a number of choices for doing an FTA. The speaker can use bald-on-record, off record, or on-record strategies.

\subsection{Bald-on-record strategies}

Bald-on-record strategy is usually performed by means of a direct speech act which is unambiguous and concise such as the use of imperatives. According to the data of this study, participants have used this strategy in performing their requests. In example 1, the conversation is between a customer (C2) and a call-centre-customer service (CCCS) employee (E2). 
Example 121 E2 tudxul Sar risa:law tiћðifha

Open the message and delete it.

E2 in line 21 uses the imperative form in order to make his request to $\mathrm{C} 2$ to delete the

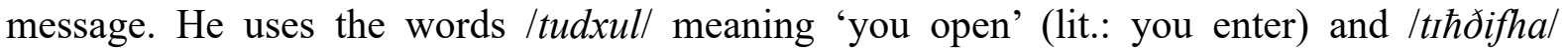
meaning 'you delete'. Both words imply commands since they are in the indirect imperative forms, thus they are direct requests, a bald-on-record strategy.

Example 29 E5 walay himmak (.) thammalnı laћaza:t

Don't worry. Be patient for moments.

Another instance is provided by E5 in example 2 who also uses an imperative verb /thammalnI/ 'be patient' (lit.: bear with me) with a time adverbial /lahaza:t/ 'moments' requesting $\mathrm{C} 5$ to allow him some time to fulfil his request. However, the request of E5 is preceded by /walay himmak/ 'don't worry' in order to soften C5's request and put him at ease. Moreover, E5 makes a short pause before he performs his request to make clear that it is a request to the hearer, $\mathrm{C} 5$.

E5's expression '/thammalni lahaza:t/' is a common one in the Jordanian context as evident in the previous studies. For instance, Al-Qudah (2017) found that /mumkın lahzah/, which has the same meaning of /thammalni lahaza:t/, a common attention getter used by Jordanians to attract the attention of the addressee.

In example 3, E10 uses a clear and unambiguous structure with a direct imperative to perform his request. His request is bald-on-record since it is a kind of help that he is going to provide for $\mathrm{C} 10$ to solve the problem of her Internet connection. In line 13, he says /zawwI:dni bnafsIr raqam/ 'give me the same number'; the verb /zawwId/ 'give' (lit.: provide) is in imperative form that makes an explicit precise request that involves no redressive action.

The request is performed by the use of the verb /zawwid/ 'give' in an attempt to achieve the 'maximum efficiency' of the action which is very important for him in this conversation paying no attention to the wants of C10's face (Brown \& Levinson, 1987, p. 95).

\section{Example 313 E10 ukeı zawdı:ni bnafsir raqam la?at?akkad minnu mıyyıh bil miyyıh \\ OK, give me the same number so I can be $100 \%$ sure about it.}

According to Grice's Cooperative Principle (CP), interlocutors have to keep in mind four maxims in order to produce appropriate conversational behavior; one of these maxims in the maxim of manner which recommends that speakers be brief and avoid ambiguity Grice (1975). Participants of this study are found to be adhering to this maxim by making their requests unambiguous using bald-on-record strategies.

\subsection{On-record Strategies}

On-record act with redressive action can stress either positive politeness or negative politeness strategies. 


\section{Macrothink}

\subsubsection{Positive-politeness Strategies}

Positive-politeness strategies are directed to the hearer's positive face; his constant desire that his wants should be thought of as desirable. In this kind of politeness, the range of redress is extended to include expressions of similarity between the two parties, the speaker and the hearer (Brown \& Levinson, 1987, p. 101). Positive politeness involves the use of utterances as a kind of metaphorical extension of intimacy in order to point towards a common ground. This may take place even between strangers who view themselves while interacting as somehow similar. In this way, the techniques of positive politeness are used not only for FTA redress, but also for signaling closeness in which the speaker tries to show that he wants to come closer to the hearer.

One of the positive-politeness strategies is that the speaker claims a 'common ground' with the hearer to imply that both of them belong to the same group or category who share some wants. In this way, the speaker stresses common membership to such a group while interacting with the hearer, thus conveying an in-group membership which can be indicated by the use of address forms, and of language or dialect to stress closeness between the speaker and the hearer.

In the present study, participants used one address form / $2 u x t /$ ' 'my sister' to indicate in-group membership. In example 4, line 8, C7 used this address form with some modification /xayti/ 'my sister (diminutive)' before his request to E7. Another instance of the same form is also repeated by the $\mathrm{C} 7$ in line 38 when thanking $\mathrm{E} 7$ for her help.

\section{Example 48 C7 xaytı baddI Pastafsır San farla bası:țah bas (.) Pana: \\ GIndI xattif fo:r d3I: tama:m}

I want to inquire about a simple thing, sister. My line is $4 \mathrm{G}$, $\mathrm{OK}$ ?

9 E7 ukeI

OK.

\section{C7 Pafkurık xaytı wallahı ma: qașsartı}

Thank you, sister. Thanks.

\section{E7 Palla yisSdak}

May God grant you happiness.

What can be observed here is that the frequency of the use of the address form indicating closeness or in-group relationship seems to be more when male participants interact with female participants than when they interact with male participants. In this regard, Al-Khawaldeh (2014) states that the use of such addressing terms including /?uxtI/ 'my sister' in the Jordanian society suggests that deference and politeness are favoured in the Jordanian culture. The use of this strategy by male participants of this study in addressing the female listeners agrees with the results of the study of Al-Khawaldeh and Zegarac (2013) who 
investigated gender and communication of gratitude in Jordan. Their study indicated that women tend to use both direct and indirect expressions when communicating with other women more than they do when interacting with men. Whereas the strategies used by men interacting with other men are simple and direct, their strategies in addressing women are various including address terms like / PuxtI/ 'my sister'. As far as the term / $2 u x t I /$ is concerned, Al-Qudah (2017) found that it is used by his Jordanian speakers of Arabic participant when addressing strangers who are of the same age of the speaker.

\subsubsection{Negative-Politeness Strategy}

Negative-politeness strategy includes a number of sub-strategies: pluralise the person responsibility, be conventionally indirect, give deference, and apologize. They are discussed below.

\subsubsection{Pluralise the Person Responsibility}

One of the negative-politeness strategies is to impersonalise the speaker (S) and the hearer $(H)$. In other words, it is to avoid the use of the singular pronouns 'you' and 'I'. This can be achieved, according to Brown and Levinson (1987, p. 198), by the pluralisation of the 'you' and 'I' pronouns. This strategy is found to be used by the participants of this study in a number of situations. First instance is when the employee (E) is asking the caller for his/her name at the beginning of the conversations. They use 'we' instead of ' $I$ ' indicated by the prefix /nI/- 'we (present)' as in the word /nitSarrafl 'we will know' instead of using the first person singular present tense morpheme / $\mathrm{Pa} /$ - ' $\mathrm{I}$ ' which results in /nitGarrafl instead of /PatSarrafl. which appeared in a number of conversations, for example conversation 4 in example 5 below.

Example $5 \quad 3 \quad$ E4

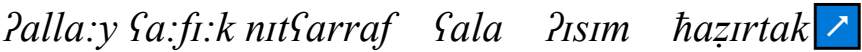

May God grant you health. May I know your name?

More politeness is also shown in example 5 by the use of certain terms that show respect to $\mathrm{H}$ such as /hazırtak/ 'you (respect form)' (lit.: your presence).

Similar example is found in conversation 5 shown in example 6 where E5 uses the word Initfarrafl which means 'we will be honoured'. It adds more politeness to the request for the name of the caller, $\mathrm{C} 5$, as it shows respect to the hearer.

Example $6 \quad 4 \quad$ E5

Palla:y Sa:fi:k ya: rab (.) nitfarraf bil PIsm

Hello. May I know your name?

Evidence of politeness in the use of /nitfarraf/ also comes from Al-Khawaldeh's (2014) study in which she states that Jordanians use this form in making a repayment for giving directions (p. 242). Similar to this study, the first person pronoun is pluralised in the example provided by Al-Khawaldeh (2014), so 'we will be honoured' instead of 'I will be honoured'. 
In the literature, Samarah (2015) indicated the use of pluralisation of the singular second person in the Arabic society, especially when addressing old people, boss, rich, leader which is considered as a kind of showing respect to the addressee. However, in this study these variables are not investigated, so the use of pluralisation can be attributed to the fact that employees consider customers superior to them since it is the employees' duty to help the customers in solving their various difficulties with their lines, network, connection, etc.

\subsubsection{Be Conventionally Indirect}

In this politeness strategy, the speaker achieves two desires: the desire to give the hearer an option not to perform the act by being indirect, and the desire to go on record. This is attained by the use of the conventional indirectness in which phrases and sentences have contextually unambiguous meanings which are different form the literal meanings they have. For example, an interrogative sentence is not used to obtain information about something but to achieve a

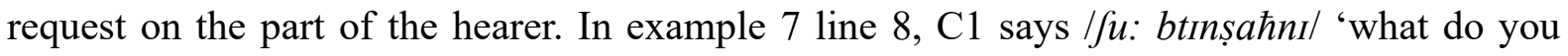
advise me?' but in the context he explains to E1 his wish to convert his subscription to something better. He uses the structure /fu: btınșaћni/ that appears at the first sight as a question, but C1's intended meaning is something like 'advise me' which is an imperative to perform the speech act of request. So, the use of the interrogative form indicated by the question word / $u$ :/ 'what' makes the request indirect, a polite request. It is evident that $\mathrm{C} 1$ 's question is for a request form E1's response in line 9 in which he explains the company offers to $\mathrm{C} 1$. Again, $\mathrm{C} 1$ repeats his request for the advice in line 10 in his question /wernıl Pafzal/ 'which one is the best?'

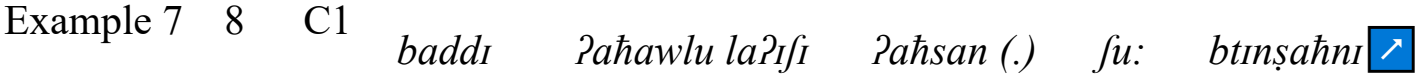

I want to change it to something better. What do you advise me?

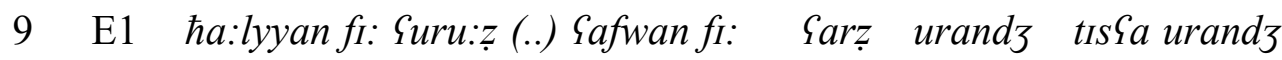

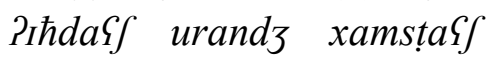

Currently we have offers, sorry, there is an Orange's offer 9, Orange 11, and Orange 15.

$10 \mathrm{C} 1$

\section{wernıl ?afẓal}

Which one is the best?

The analysis of the directness and conventional indirectness strategies shown in the above sections on bald-on-record strategies and be conventionally direct under negative-politeness strategies reveal that the conventional indirectness is preferred to the direct strategy by the participants of this study.

In relation to the previous studies conducted in the Arabic culture context, the findings of this study agree with their findings that the preference of the participants for direct or conventional indirect strategies. For example, the non-conventional indirect strategies are not preferred by the participants of this study as a single example is not found in the data; this 


\section{Macrothink

fact is somehow similar to the study of Alrefai (2012) who investigated the politeness strategies used by Kuwaitis people in asking for favours. She found that nonconventional indirect strategies, especially hints, are rarely used by her participants. Moreover, she found that conventional indirect strategies were strongly preferred which is similar to the findings of this study which suggests that Jordanians and Kuwaitis are similar in their ways of showing respect to other people. In both cases the choice of the strategies seems to be influenced by the participants' culture and Islamic religion. In addition to Alrefai' study, Al-Momani's (2009) study showed similar findings to those of this study in relation to participants' preference for direct and indirect strategies. His participants are Jordanian EFL learners, American English native speakers and Jordanian Arabic native speakers. He found that the three groups prefer conventional indirect strategies to direct strategies in their request speech act realisation. He attributed the reason of similarity between Jordanian EFL learners and Jordanian native speakers of Arabic in their preference to the fact that the cultural norms are deeply ingrained in them and strongly influence their linguistic choices in their Jordanian Arabic and second/foreign language.

\subsubsection{Give Deference}

In this negative-politeness strategy, the speaker humbles and lowers himself and raises the hearer by indicating that the hearer is of a higher social status or superior to the speaker (Brown \& Levinson, 1987, p. 178). In the present study, participants use some honorific terms that are both humiliative and deferential. Such terms are used to reduce the effect of the FTA on the hearer.

One of the honorific terms that the speakers frequently use is /hazirtak/ 'you' (lit.: your presence). It accompanies not only requests but also information questions. One frequent use of / hazırtak/ in information questions is noticed at the beginning of the conversations where $\mathrm{E}$ normally asks $\mathrm{C}$ about his/her name. as in Example 5 above.

However, since the social status of the participants is not easily detected, we can interpret the situation in the following way: on the one hand, the employees' duty at this service centre is to help customers with their difficulties related to their lines, network, subscription, etc. and on the other hand, the caller, after the call ended, evaluates the service including the way the employee responded to him/her. In this way, employees always view callers as superior to them and of a higher status since they are going to evaluate them. For this reason, terms like / hazirtak/ are frequently seen with questions and requests.

Example $8 \quad 9 \quad$ E8

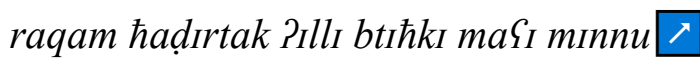

Your number is the one you are speaking form?

15 E8

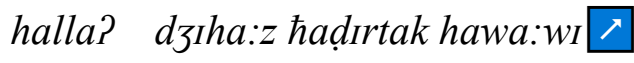

Now is your device Huawei? 
In example 8, E8 wants to make sure that it is the same number that C8 is using at the time of the call, so simply she could use in line 9 /raqamak/ instead of /raqam hadirtak/. Both means the same: 'your number', but the latter shows more respect to $\mathrm{C} 8$ since the inclusion of /hadırtak/. Similar use is repeated by E8 in line 15 in which/dzıha:z hadırtak/ is used instead of /dzıha:zak/ meaning 'your device'.

The use of the term / $\hbar a z$ Irtak/ by the participants of this study agrees with the previous study findings. For instance, Samarah (2015) pointed out that this term is a special title of respect used in the Arabic society when the speaker would like to express his or her respect for the other which is similar to the use of /hazirtak/ in the above examples.

Now, the insertion of /yareit/ 'I hope' at the beginning of the request is meant to show difference to C2. In other word, E1 uses /yareit/ which indicates a kind of wish from the speaker to the hearer to perform the act. So, making the command a wish and thus E2 is giving deference to $\mathrm{C} 2$ as shown in example 9 below.

\section{Example $9 \quad 9 \quad$ E2 yareIt tithammalnı \\ I hope that you can be patient.}

In example 9, E2 requested C2 to allow him some time in order to check his line. In line 9, C2 says /yareit tithammalni/ 'I hope that you can be patient' which could be simply said as 'wait a minute' but to show some deference to C2, E2 includes his wish /yareit/ to C1 for being patient in addition to the expression /tithammalni/ (lit.: you bear with me). The time that E2 needs for checking C2's line is meant to help him for checking his line and solve the problem he encounters in spite of that E2 makes the problem as his own problem by saying Itithammalni/, thus lowering himself and raising $\mathrm{C} 2$, a kind of politeness.

Seeking the hearer permission for the request is another technique of giving deference to the hearer to reduce the effect of the FTA on him or her. It may be achieved by the use of /law samaht/ 'if you please'. Example 10 provides an instance of this technique.

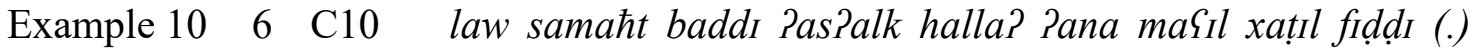

tama: $m$

If you please, I want to ask you, now I have the silver line, $\mathrm{OK}$ ?

In example 10, $\mathrm{C} 10$ wants to inquire about something about her silver line. Being a subscriber, she could directly ask E10 to perform her request; instead, she first uses the structure /baddI/ 'I want to' which is also used in some conversations by other customers at the beginning of their calls immediately after the greeting. C10 adds the structure /law samaht/ before /baddI/ asking permission from E10 as it appears from the literal meaning of the structure in line 6 . But the intended meaning is different as she is not waiting for his permission to say 'yes, I allow you?' or something similar; her intended meaning is to ask him about her silver line and the use of /law samaht/ is only to give deference to E10 by raising him and indicating his power over her. 


\section{Macrothink

Samarah (2015) described the term /law samaht/ as very common and important to use when speaking to someone unknown to you. Furthermore, Al-Qudah (2017) in his study on Jordanian Arabic referred to the term /law samaht/ as an attention getter and found that it is used by Jordanians to attract the recipients' attention As far as this study is concerned, it agrees with Samarah's (2015) statement as the interlocutors in each conversation are unknown to each other.

\subsubsection{Apologize}

Negative politeness is also performed by apologizing to the hearer for doing the FTA. This can be made by signaling some reluctance to impinge on the hearer's negative face which in turn minimize effect of that impingement. This reluctance can be shown in a number of ways among which are admitting the impingement and giving an overwhelming reason (Brown \& Levinson, 1987, p. 187).

In the first technique of showing regret or reluctance, the speaker simply acknowledges that he or she is impinging on the hearer's face. For instance, in example 11, C5 uses the term /Paralbak/ 'I bother you' before his request for changing his number to a private one when addressing E5. Here, C5 admits that this kind of act is somehow bothering and threatens E5's negative face, although it is E5's duty to help him and C5 simply can say 'How can I make my number a private one?', but in an attempt to reduce the effect of the FTA act, he uses the structure /baddr:: Paralbak/ 'I will/want to bother you'. Moreover, the lengthening of the vowel in /baddr::/ provides more evidence of C5' reluctance.

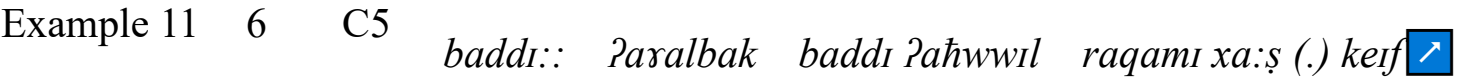 \\ I want to bother you. I want to change my number to a private one. How?}

The second technique of showing reluctance under the strategy of apologise is giving overwhelming reasons. In this way the speaker claims that he or she has a convincing reason for doing the FTA and implies that normally he or she would not be willing to infringe the hearer's negative face.

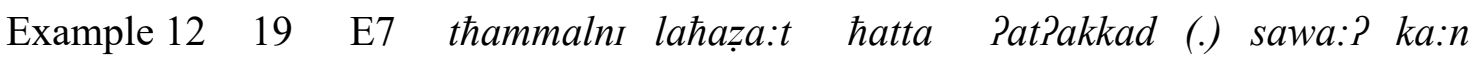
billeIl Paw binnaha:r nafsif $f_{I}: \nearrow$

Be patient for moments so I make sure ... Whether it is night or day the same thing?

$47 \quad \mathrm{C} 7$

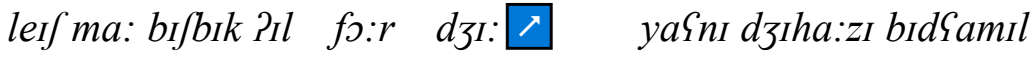

$$
\begin{aligned}
& \text { fo:r dzI: }
\end{aligned}
$$

Why doesn't 4G connect? I mean my device supports 4G. 
In example 12 line 19, E7's request to C7 is /thammalni laћaza:t/ 'be patient for moments'. In order to apologise for asking $\mathrm{C} 7$ to do so, she gives the reason for such time she requires from C7; she says /hatta Pat?akkad/ 'so I make sure'. Relating the reason to the request makes it clear to C7 that it is not E7's wish to infringe upon C7's negative face.

In the same conversation, C7 requests E7 to check why doesn't 4G connect on his line. He adds /dziha:zi bidGamil fo:r dzI:/ 'my device supports 4G' giving reason for his request, thus a way to apologise for the FTA implying that it is not his fault since his device supports $4 \mathrm{G}$ connection.

E7's strategy of using / hatta ?at?akkad/ in giving the reason as a kind of apology for the request is similar to E10's structure /la?at?akkad/ 'to be sure' in example 13 below.

\section{Example $13 \quad 13$ E10 uke zawdr:nI bnafsir raqam la?at?akkad minnu miyyih bil miyyıh \\ OK, give me the same number so I can be $100 \%$ sure about it.}

In example 13, E10's request is that $\mathrm{C} 10$ gives E10 the number related to her request. Here, E10 adds the reason why he is asking for that number starting that by the use of /la?at?akkad/. In this way, nothing is left vague for $\mathrm{C} 10$ and the potential harm of the FTA is reduced, if not removed at all.

As said above, the meaning of /li?annu/ or some of its derivatives might be implied in the structure; it is omitted from the structure once its meaning is clear. For instance, in example 14, E9 also gives the reason to C9 for requesting her to raise the volume, but simply he says the reason /PIttısa:lık reır wa:zıћ/ 'Your call is not clear.' without including /lı?annu/.

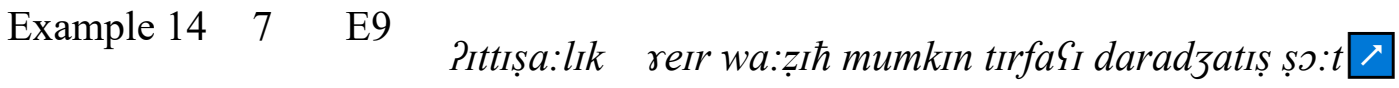

Your call is not clear. Can you raise the volume?

However, whether with or without 'because', the reason is given to apologise for the act that may damage the negative face wants of the hearer.

\section{Conclusion}

The analysis of the data has shown that negative-politeness strategies dominate the scene in making requests as they were the most frequent ones which may indicate the preference of Jordanians for these strategies to other strategies. In addition, honorificity is a striking feature of the employees' politeness structures in requests.

The results of the study revealed that participants used bald-on-record strategy in making their requests by involving the imperative forms of verbs to make their requests unambiguous and clear. The results also show that the negative-politeness strategy is preferred in many instances for performing the speech act of requests which involves the use of the plural pronouns instead of singular ones, the use of conventional indirectness by making their requests in form of questions, giving deference to the hearer by using certain honorific terms 
or by seeking their permission for the request, and the use of apologies for making the request which was performed by either admitting the impingement or giving an overwhelming reason.

The results of the study have revealed that sociocultural norms of the Jordanian society including Islamic culture were adhered to in a number of strategies of showing politeness and respect as participants strongly followed these norms in their requests, a finding indicates that the acquisition of these norms is essential for learners of Jordanian Arabic. Therefore, it might be concluded that the choice of politeness strategies is a predictor of the degree of adherence to the sociocultural norms by Jordanians as represented by the participants of this study.

Furthermore, the analysis has shown that in certain cases gender variation had an impact on the choice of particular strategies. Therefore, it is recommended that gender differences be paid some attention while engaging in any kind of interaction with Jordanians. Similarly, the reason for calling the CCCS employees had a significant role in choosing the strategy of politeness. The study recommends conducting future studies in similar organisations investigating other speech acts such as rejecting, giving advice, insult, etc.

\section{References}

Abushihab, I. (2015). Contrastive analysis of politeness in Jordanian Arabic and Turkish. Theory and Practice in Language Studies, 5(10), 2017-2022. https://doi.org/10.17507/ tpls.0510.06

Al-Harahsheh, A. (2014a). The sociolinguistic roles of silence in Jordanian society. Journal of Advances in Linguistics, 1(1), 16-23. https://doi.org/10.24297/jal.v1i1.1988

Al-Harahsheh, A. (2014b). Language and gender differences in Jordanian spoken Arabic: A sociolinguistics perspective. Theory and Practice in Language Studies, 4(5), 872-882. https://doi.org/10.4304/tpls.4.5.872-882

Al-Khawaldeh, N., \& Zegarac, V. (2013). Gender and the communication of gratitude in Jordan. Open Journal of Modern Linguistics, 3, 268-287. https://doi.org/10.4236/ojml. 2013.33035

Al-Khawaldeh, N. (2014). Politeness orientation in the linguistic expression of gratitude in Jordan and England: A comparative cross-cultural study. Unpublished Ph.D. dissertation, University of Bedfordshire, UK.

Al-Momani, H. (2009). Caught between two cultures: The realization of requests by Jordanian EFL learners. Unpublished Ph.D. dissertation, Indiana University of Pennsylvania, Indiana. PA.

Almutlaq, H., \& Jarrah, M. (2013). Salutations in Jordanian Arabic: A sociolinguistic perspective. International Journal of Social Science, 4(15), 111-114.

Al-Qudah, M. (2017). The Jordanian terms of address: A sociopragmatic study. SHS Web Conf. 37, 01080. ERPA. https://doi.org/10.1051/shsconf/20173701080 
Alrefai, E. (2012). Favor asking in Kuwaiti Arabic: Effects of power and distance on core strategies and modification. Available from ProQuest Dissertations \& Theses Global: Literature \& Language. (1039155719).

Al-Sobh, M. (2013). An analysis of apology as a politeness strategy expressed by Jordanian university students. International Journal of Humanities and Social Science, 3(2), 150-154.

Austin, J. (1962). How to do things with words. Oxford, England: Calderon Press.

Bani Mofarrej, O., \& Al-Abed Al-Haq, F. (2015). A sociolinguistic study of euphemistic death expressions in Jordanian Arabic. Arab World English Journal (AWEJ), 3(6),110-130. https://doi.org/10.24093/awej/vol6no2.9

Blum-Kulka, S., \& Olshtain, E. (1984). Requests and apologies: A cross-cultural study of speech act realization patterns. Applied Linguistics, 5, 196-213. https://doi.org/10.1093/ applin/5.3.196

Brown, P., \& Levinson, S. (1978). Universals in language usage: Politeness phenomena. In E. Goody (Ed.), Questions and Politeness: Strategies in social interaction (pp. 56-289). Cambridge: Cambridge University Press.

Brown, P., \& Levinson, S. (1987). Politeness: Some universals in language usage. Cambridge: Cambridge University Press. https://doi.org/10.1017/CBO9780511813085

Eckert, P. (1998). Gender and sociolinguistic variation. In J. Coates (Ed.), Language and gender: A reader (pp. 64-76). Oxford: Blackwell Publishers.

Eshreteh, M. (2014). A cross-cultural socio-pragmatic study of invitations in Palestinian Arabic and American English. Unpublished Ph.D. dissertation, Universidad Complutense de Madrid, Madrid.

Eslami, Z., \& McLoed, K. (2010). It's 8 o'clock in the morning - are you watching television? Teaching indirect requests. In D. Tatsuki, \& N. Houck (Eds.), Pragmatics from research to practice: Teaching speech acts (pp. 19-28). Alexandria, Virginia: Teachers of English to Speakers of Other Languages, Inc.

Goffman, E. (1967). Interaction ritual: Essays on face-to-face behaviour. New York: Doubleday Anchor.

Green, G. (1996). Pragmatics and natural language understanding. Mahwah, NJ: Lawrence Erlbaum Associates.

Grice, H. (1975). Logic and conversation. In P. Cole, \& J. Morgan (Eds.), Syntax and Semantics 3 (pp. 41-58). New York: Academic Press.

Grice, H. (1989). Studies in the way of words. Massachusetts: Harvard University Press.

Holmes, J. (2008). Introduction to sociolinguistics (3rd ed.). Pearson Longman: New York

Ji, S. (2000). Face and polite verbal behaviors in Chinese culture. Journal of Pragmatics, 32(7), 1059-1062. https://doi.org/10.1016/S0378-2166(99)00068-5 


\section{Macrothink

Kasper, G. (1998). Interlanguage pragmatics. In H. Byrnes (Ed.), learning second and foreign languages (pp. 183-208). New York: The Modern Language Association of America.

Migdadi, F. (2003). Complimenting in Jordanian Arabic: A socio-pragmatic analysis. Unpublished Ph.D. dissertation, Ball State University. Muncie, Indiana.

Rababa'h, M., \& Malkawi, N. (2012). The linguistic etiquette of greeting and leave-taking in Jordanian Arabic. European Scientific Journal, 8(18), 14-28.

Samarah, A. (2015). Politeness in Arabic culture. Theory and Practice in Language Studies, 5(10), 2005-2016. https://doi.org/10.17507/tpls.0510.05

Searle, J. (1969). Speech acts: An essay in the philosophy of language. Cambridge: Cambridge University Press. https://doi.org/10.1017/CBO9781139173438

Searle, J. (1975). Indirect speech acts. In P. Cole, \& J. Morgan (Eds.), Syntax and semantics (pp. 168-183). New York: Academic Press. https://doi.org/10.1163/9789004368811_004

Searle, J. (1976). A classification of illocutionary acts. Language in Society, 5(1), 1-23. https://doi.org/10.1017/S0047404500006837

Searle, J. (1979). Expression and meaning. Cambridge: Cambridge University Press. https://doi.org/10.1017/CBO9780511609213

Trosborg, A. (1995). Interlanguage pragmatics: Requests, complaints and apologies. Berlin: Mouton de Gruyter. https://doi.org/10.1515/9783110885286

Uso-Juan, E. (2010). Requests: A sociopragmatic approach. In A. Martinez-Flor, \& E. Uso-Juan (Eds.), Speech act performance theoretical, empirical and methodological issues. Amsterdam: John Benjamins Publishing Company. https://doi.org/10.1075/11lt.26.14uso

Yule, G. (1996). Pragmatics. Oxford: Oxford University Press.

Note 1. Irbid is a city situated in north of Jordan.

\section{Copyright Disclaimer}

Copyright reserved by the author(s).

This article is an open-access article distributed under the terms and conditions of the Creative Commons Attribution license (http://creativecommons.org/licenses/by/3.0/). 